\title{
PENGARUH KONFLIK KERJA, STRES KERJA, DAN BEBAN KERJA TERHADAP KINERJA KARYAWAN PT. MUTIARA HUTAMA SUKSES
}

\author{
winner clinton purba ${ }^{1)}$, sri langgeng ratnasari ${ }^{2)}$ \\ ${ }^{1}$ Program Studi Manajemen, Universitas Riau Kepulauan \\ winer2309@gmail.com \\ ${ }^{2}$ Program Studi Magister Manajemen, Universitas Riau Kepulauan \\ sarisucahyo@yahoo.com
}

\begin{abstract}
Employee Performance is a major concern in organizations, because employee performance determines organizational performance. The purpose of this study was to determine the effect of work conflict on employee performance, to determine the effect of work stress on employee performance, to determine the effect of workload on employee performance, and to determine the effect of work conflict, work stress, and workload on employee performance. This research method uses quantitative methods. The research population is employees of PT. Mutiara Hutama Sukses as many as 40 people. The technique used in determining samples is to use the census method. Testing the hypothesis in this study using the $t$ test, and $f$ test to determine the effect of the overall research, with the help of SPSS 21 for Windows. The results of this study are: work conflict has a significant effect on employee performance, work stress has a significant effect on employee performance, workload has no significant effect on employee performance. The results showed that F_Count was 30,798 with a significant value of F_Count of 0,000 lower than 0.05 while the value of $F_{-}$Table at the confidence level of $95 \%(\alpha=0.05)$ was 2.87 for work conflict, work stress and workload together same effect on employee performance.
\end{abstract}

Keywords: Work Conflict, Job Stress, Workload, Employee Performance

\begin{abstract}
ABSTRAK
Kinerja Karyawan menjadi perhatian utama dalam organisasi, karena kinerja karyawan menentukan kinerja organisasi. Tujuan penelitian ini adalah untuk mengetahui pengaruh konflik kerja terhadap kinerja karyawan, untuk mengetahui pengaruh stress kerja terhadap kinerja karyawan, untuk mengetahui pengaruh beban kerja terhadap kinerja karyawan, dan untuk mengetahui pengaruh konflik kerja, stress kerja, dan beban kerja terhadap kinerja karyawan. Metode penelitian ini menggunakan metode kuantitatif. Populasi penelitian adalah karyawan PT. Mutiara Hutama Sukses sebanyak 40 orang. Teknik yang digunakan dalam menetukan sampel adalah dengan menggunakan metode sensus. Pengujian hipotesis dalam penelitian ini menggunakan Uji t, dan Uji f untuk mengetahui pengaruh penelitian secara keseluruhan, dengan bantuan program SPSS 21 for Windows. Hasil penelitian ini adalah: konflik kerja berpengaruh signifikan terhadap kinerja karyawan, stress kerja berpengaruh signifikan terhadap kinerja karyawan, beban kerja berpengaruh tidak signifikan terhadap kinerja karyawan. Hasil penelitian menunjukkan bahwa $F_{-}$Hitung adalah 30,798 dengan signifikan nilai $F_{-}$Hitung sebesar 0,000 lebih rendah dari 0,05 sedangkan nilai $F_{-}$Tabel pada tingkat kepercayaan 95\% $(\alpha=0,05)$ adalah 2,87 untuk itu konflik kerja, stres kerja dan beban kerja secara bersama-sama berpengaruh terhadap kinerja karyawan.
\end{abstract}

Kata kunci: Konflik Kerja, Stres Kerja, Beban Kerja, Kinerja Karyawan 


\section{PENDAHULUAN}

Manajemen Sumber Daya Manusia merupakan bagian yang tidak terpisahkan dari sistem sebuah manajemen perusahaan, dimana manajemen sumber daya manusia memiliki pengaruh terhadap kinerja dan aktivitas yang ada didalamnya sehingga dalam hal ini ada begitubanyak hal mengenai sistem dan peraturan kerja. Oleh karena itu salah satu faktor yang menjadi pendukungnya berjalan SDM yaitu kerjasama agar dalam menjalankan sistem manajemen yang ada selain itu dalam meningkat mutu kualitas karyawan dengan mengadakan pelatihan dan dasar-dasar pemahaman cara kerja yang efektif dan efisien dikarenakan itu sebagai wadah dan cara menilai program itu bias diterima atau tidak dalam keseimbangan sebenarnya, mengacu pada hal ini ada berbagai macam hal yang akan dibahas dalam kerja dan masalah kerja yaitu adanya konflik kerja, stress kerja dan beban kerja terhadap kinerja karyawan di PT.Mutiara Hutama Sukses menilai dari permasalahan kerja yang ada didalam perusahaan ataupun diluar masalah secara pasti dan tidak disengaja masalah selalu saja hadir ketika dalam bekerja baik secara umum dan kecil dilingkungan kerja. Konflik Kerja adalah permasalahan yang terjadi ketika bekerja atau sedang melaksanakan aktivitas di dalam bekerja, stress kerja sendiri berasal dari konflik kerja karena masalah yang timbul akibat kerja menjadi lebih nyata dan sangat berpengaruh sekali baik itu secara transparan maupun linear, beban kerja dalam hal setelah seseorang melaksanakan pekerjaannya tapi tidak bias menuntaskannya maka akan berdampak menjadi beban untuk diri sendiri yang dimana pekerjaan tersebut harus dituntaskan baik itu perlahan tapi berjalan sesuai koridornya. Menurut Ahmadi (2010:13) ada berbagai macam hal terjadinya konflik,stress, beban kerja di dalam dunia kerja terutama.dari awal samapai akhir menuju planning yang diinginkan perusahaan secara umum dan internal baik dari kalangan perusahaan besar dan kecil. Dalam hal ini konsep kinerja karyawan Menurut Mangkunegara dalam Cairudin (2012:3) adalah hasil kerja karyawan yang secara kualitas dan kuantitas sangat berpengaruh terhadap perusahaan yang dimana ia bekerja untuk menyesuaikan situasi dan keamanan bekerja agar sesuai dengan prosedur kerja yang berlaku baik dalam pekerjaan maupun kerjasama antar rekan kerja di perusahaan.

Menurut Siagian (2014:400) Stres meruapakan kondisi ketegangan atau kepanikan yang berpengaruh terhadap emosi atau jalan pikiran dan kondisi sesorang yang sedang tidak kondusif dalam bekerja sehingga terkadang tidak sanggup ia hadapi dengan nyata dan kesabaran makanya muncullah stress berkepanjangan akibat dari tugas dan kerja yang tidak selesai juga.

Istilah Stres Kerja juga terkadang menjadikan banyak orang lupa akan berpikir bagaimana cara menyelesaikan masalah kerja dan mencari solusi agar apa yang diinginkan oleh perusahaan dapat dimaksimalkan sebaik mungkin untuk arah kerja yang transparan serta akuntabilitas professional dalam bekerja 


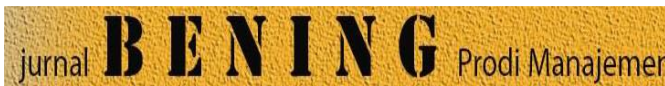
UNIVERSITAS RIAU KEPULAUAN BATAM

\section{Konflik Kerja}

Konflik Kerja berasal dari kata konflik yang berarti satu permasalahan bagi seorang karyawan atau dunia konflik kerjaa.

Menurut Haryati

Konflik Kerja dapat diartikan sebagai permasalahan kerja yang dimana pekerjaan tersebut belum bisa diselesaikan tapi sudah meminta hal yang lain karena oleh itu dapat ditemukan didunia kerj yaitu rasa ego dan keinginan diri tidak bisa terkontrol baik secara persuasip dan parsial hal seperti ini harus diawasi.

Menurut Siswandi (2012:104) manajer dalam konflik kerja ini harus ikutuserta dalam memcahkan masalah yaitu dengan hadir ditengahtengah menjadi moderator atau memediasikan karyawan yang sedang bermasalah atau memiliki perbedaan pendapat agar tidak menjadi lama nantinya.

Manajer adalah seorang pemimipin di perusahaan baik itu secara umum dan sempit dalam status pekerjaan banyak hal yang harus diteliti oleh seorang manajer mengenai permasalahan kerja, permasalahan intern, sistem dan peraturan kerja untuk banyak saat ini perusahaan mengerti menjalankan prosedur kerja tapi ia lupa kalau ada peran manajer sebagai pendamping untuk mengatur dan menjaga elektabilitas kerja sebagai panduan dan tata tertib perusahaan untuk terus berkombinasi secara menyeluruh. Untuk itu tugas seorang pemimpin dalam dunia kerja ialah menjadi penengah dalam setiap kerja baik itu waktu dan hal mengenai tata tertib kerja agar rencana yang diinginkan bisa berjalan sesuai harapan perusahaan dan karyawan menjadi majemuk dalam suatu ikatan kinerja dan profesionalitas kerja dalam tatanan sistem.

Ada beberapa indikator secara umum yang berkaitan dengan konflik kerja Menurut Suyono (2013:30) sebagai berikut: Adanya perbedaan pendapat, adanya perbedaan pendapat antara karyawan itu sangat murni terjadi dikarenakan adanya solusi dan saran yang berbeda dari setiap anggota atau karyawan yang bekerja, demi memajukan dan membuat perusahaan berkembang pesat adanya perbedaan tersebut menjadikan sistem kerja semakin kuat. Adanya visi dan misi berbeda, dalam hal banyak sekali keragaman perbedaan mengenai tujuan dan maksud dalam konflik kerja yaitu pola yang dipikirkan dengan apa yang dijalankan tidak seimbang sehingga selalu berubah

Ada beberapa sifat konflik yang terdapat didalam sistem kerja, Menurut Siswandi (2012:105).

\section{Konflik Laten}

Konflik ini terjadi ketika kondisi konflik muncul

2. Konflik Yang dikenal

Orang atau kelompok mulai mengetahui bahwa konflik benar-benar ada dan terjadi.

3. Konflik Manifes

Konflik yang dimana semua pohak terlibat dalam konflik sama-sama menyadari ada untung dan ruginya.

\section{Cara Penanganan Konflik}

1.

Mengintegrasikan

Pihak yang berkepentingan di hubungi untuk melihat permasalahan yanag ada dan mencari solusi yang terbaik untuk selesai.

2. Membantu

Pihak yang membantu untuk kepentingan diri sendiri atau kepentingan orang lain sering 
terjadi dalam permasalahan kerja

3

Gaya ini sesuai digunakan untuk memaksa pihak yang terlibat untuk tadinya sulit mengakui perbuatan atau kesalahan yang pertama

4. Menghindar

Cara ini sangat diutamakan dalam menghadapi permasalahan yang ada dikarenakan adanya unsur menghindari diri dari konflik kerja yang ada.

\section{Stres Kerja}

Stres kerja adalah suatu kondisi yang terjadi pada karyawan atau seseorang yang diharapkan boleh mencapai solusi dan hasil yang diminta oleh perusahaan atau individu lainnya agar sesuai dengan target perusahaan yang akan dicapai nantinya berdasarkan apa yang dibuat sesuai tugas masing-masing.

Dalam hal ini berkaitan sesuai dengan perancangan awal sebuah perusahaan yang memiliki hasil yang diinginkan baik secara umum dan sempit dalam artiannya, dalam hal ini ada beberapa hal atau aktivitas yang harus dikerjakan untuk memaksimalkan aktivitas kerja yang berjalan sesuai aturan dan norma yang benar Susilo (2012:20) berpengaruh terhadap kinerja karyawan dan produktivitasnya baik secara perusahaan internal yaitu:

1.

Komunikasi

Komunikasi dalam hal ini adalah suatu hubungan yang dibangun oleh interaksi sesame rekan kerja yang tujuannya agar membangun komunikasi dan kerjasama

2. Kerjasama
Kerjasama adalah hubungan atau pola dalam kerja baik itu tim dan

kelompok yang saling membutuhkan dan menjadi team work dalam perusahaan

3. Motivasi

Motivasi adalah suatu dorongan atau semangat untuk melaksanakan pekerjaan atau tanggung jawab terutama apabila sedang mengalami stress kerja hal yang berpengaruh

$4 . \quad$ Saran

Saran adalah suatu hal yang berhubungan dengan ke 3 hal tersebut atau kinerja karyawan diperusahaan dapat berkembang pesat.

\section{Sumber-Sumber Potensi Stres}

Ada 3 kategori potensi pemicu stress (stressor) Menurut Robbins (2012:35) adalah sebagai berikut:

1. Faktor lingkungan, ketidak pastian lingkungan mempengaruhi tingkat stress para karyawan, perubahan dalam siklus bisnis menciptakan ketidakpastiam dalam pekerjaan.

2. Faktor pribadi, factor ini menjadi hal utama masalah keluarga yaitu ekonomi pribadi atau kepribadian dan karakter seseorang

3. Faktor organisasi, faktor ini terkadang menjadi tekanan untuk menghindari masalah yang ada saat ini tidak selalu peka terhadap kegiatan atau aktifitas kerja, beberapa diantaranya:

a. Tuntutan tugas

Dalam hal ini berkaitan dengan tuntutan 
seseorang yang meliputi aspek kerja nyata

b. Tuntutan Peran

Dalam hal ini berlaku dan saling berkaitan dengan fungsi yang diberikan tugas atau tanggung jawab dengan cepat.

Pada hal lain pihak stress kerja juga disebabkan masalah-masalah yang terjadi diluar perusahaan. Penyebabpenyebab stress "off-the job" antara lain:

1. Kekuatiran Finacial

2. Masalah-Masalah yang bersangkutan dengan anakanak

3. Masalah dengan fisik

4. Perubahan-Perubahan ditempat tingga

5. Masalah pribadi dan lain

\section{Beban Kerja}

Beban kerja merupakan aspek pokok yang sangat penting dalam proses bekerja yang dimana sangat berpengaruh terhadap sikap dan tingkah laku seorang karyawan disaat ia melaksanakan tugas dan tanggung jawabnya dalam bekerja. Menurut

Dhania (2012:45) menyebutkan beban kerja juga adalah sejumlah kegiatan yang membutuhkan keahlian tertentu dimana baik secara fisik dan psikis selain itu beban kerja juga tertentu yang dimana merupakan bagian terpenting dalam menyelsaikan masalah kerja yang akan di hasilkan oleh perusahaan berdampak bagi karyawan itu sendiri.

\section{Faktor-Faktor Beban Kerja}

Ada beberapa faktor yang mempengaruhi beban kerja Menurut Mariadi (2012:85) menyatakan faktor- eksternal, yaitu beban yang bertiasal dari luar pekerjaan seperti:
1. Tugas Tugas yang bersifat fisik, ruang kerja, sikap kera, tugas/tugas bersifat psikologis

2. Organisasi kerja, seperti lamanya waktu bekerja, waktu istirahat, shiff kerja dan penguapahan

3. Lingkungan kerja, lingkungan kerja fisik, lingkungan kimiawi, lingkungan kerja biologis dan psikologis

Faktor internal, faktor internal adalah faktor yang berasal dari dalam pekerjaan akibat reaksi dengan faktor eksternal itu sendiri. Selain itu faktor internal meliputi berbagai bagian (jenis kelamin, umur, dan gizi), faktor psikis (motivasi, persepsi, kepercayaan, keinginan dan kepuasan).

\section{Jenis Beban Kerja}

Beban kerja meliputi 2 jenis, sebagaimana dikemukakan oleh munandar (2012:120). Ada 2 jenis bebabn kerja:

A. Beban kerja kuantitatif meliputi

1. Harus melaksanakan observasi karyawan secara pasti selama jam kerja

2. Banyaknya pekerjaan dan beragam tugas penting yang harus dijalankan

3. Komunikasi langsung antara karyawan dan atasan lainnya

\section{Dampak Beban Kerja}

Beban kerja yang terlalu berlebihan akan mengakibatkan stres kerja baik fisik maupun psikis dan reaksi-reaksi emosional, seperti sakit kepala dan gangguan lainnya, sedangkan pada beban kerja yang 
terlalu sedikit dimana pekerjaan yang mudah marah dalam hal ini kebosanan sehari-hari karena tugas dan pekerjaan yang terlalu sedikit mengakibatkan kurangnya perhatian pada pekerjaan.

\section{Kinerja Karyawan}

Kinerja karyawan adalah hasil kerja secara kualitas dan kuantitas yang dicapai oleh seorang karyawan di perusahaannya, dalam melaksanakan tugas dan tanggung jawab sesuai aturan sistem yang berlaku kepadanya.

Darrmawan, (2012:130) kinerja karyawan dipengaruhi beberapa faktor yaitu:

a.

Kemampuan
Pada dasaranya faktor
kemampuan terdiri daro
kemampuan potensi/Skill
Faktor Motivasi

Faktor mental, di mana faktor mental para karyawan ditentukan oleh sikap kerja dalam menghadapi masalah

Adapun aspek-aspek standar kinerja Menurut Darmawan (2012:45) terdiri dari aspek kuantitatif dan aspek kualitatif. Aspek kuantitatif:

1. Proses cara kerja dan kondisi pekerjaan

2. Waktu yang digunakan lama atau tidaknya pekerjaan

3. Jumlah dan jenis pemberian pelayanan dalam bekerja

Untuk spek kualitatif meliputi:

1. Ketepatan kerja dan kualitas pekerjaan

2. Tingkat kemampuan dalam bekerja.

3. Kemampuan menganalisis data atau informasi, kemampuan dan kegagalan dalam menggunakan mesinmesin dan peralatan

METODE PENELITIAN

\section{Teknik Pengambilan Sampel}

Populasi adalah wilayah generalisasi yang terdiri atas objek atau subyek yang mempunyai kualitas dan karakteristik tertentu yang ditetapkan oleh peneliti untuk dipelajari dan kemudian ditarik kesimpulannya, Sugiyono (2014:115). Populasi dalam penelitian ini ialah seluruh karyawan di PT. Mutiara Hutama Sukes yang berjumlah 40 orang.

Sampel adalah bagian dari jumlah dan karakteristik yang dimiliki oleh populasi tersebut Sugiyono (2014:123) sensus adalah metode yang digunakan untuk mendapatkan hasil dari populasi yang dimiliki tidak melebihi 100 ke atas, selain itu juga memiliki tingkat kesalahan lebih sedikit.

\section{Teknik Pengumpulan Data}

Teknik pengumpulan data adalah suatu metode yang dapat mengukur atau mengatur sumber dari beberapa alternatife yaitu dengan cara interview dan kuesioner" berdasarkan pengertian tersebut terdapat beberapa cara digunakan dalam pengumpulan data untuk penelitian ini.

\section{Kuesioner}

Kuesioner merupakan teknik pengumpulan data yang dilakukan dengan cara memberikan seperangkat pertanyaan atau pernyataan tertulis pada responden untuk dijawabnya, selain itu kuesioner juga merupakan teknik pengumpulan data yang efisien bila peneliti mengetahui dengan pasti variable yang akan di ukur dan akan tau apa yang bisa diharapkan dari responden dan juga kuesioner cocok digunakan bila jumlah responden 
cukup besar dan tersebar di wilayah yang luas lagi.

\section{Teknik Analisis Data}

a.

Uji Validitas

Uji validitas adalah suatu derajat ketepatan antara data yang sesungguhnya terjadi dengan data yang dapat dikumpulkan oleh peneliti. Sugiyono dalam Hasibuan (2012:17), validitas dalam penelitian dijelaskan sebagai salah satu derajat ketepatan pengukuran tentang isi dari pernyataan yang penulis buat. Teknik uji yang digunakan adalah teknik korelasi melalui koefisien korelasi product moment. Skor ordinal dari setiap item pertanyaan yang diuji validitasnya dikorelasikan dengan skor ordinal keseluruhan item, jika koefesien tersebut itu positif, maka item tersebut valid, valid berarti instrument tersebut dapat digunakan untuk mengukur apa yang seharusnya diukur.

$\mathrm{n} \sum \mathrm{xy}-\sum \mathrm{x} \sum \mathrm{y}$

$\left.\sqrt{\left(\mathrm{n} \sum \mathrm{x} 2\right)}-\left(\sum \mathrm{x}\right) 2\right)\left(\mathrm{n} \sum \mathrm{y} 2\right)-$ $\left.\left(\sum \mathrm{y}\right) 2\right)$

Keterangan:

$\mathrm{r}$ hitung : Koefisien korelasi

$\begin{array}{ll}\sum \mathrm{X} 1 & : \text { Jumlah skor item } \\ \sum \mathrm{Y} 1 & : \text { Jumlah skor total } \\ \mathrm{n} & \text { Jumlah } \\ & \text { responden }\end{array}$

Menurut Sugiyono (2011:105) syarat minimum untuk dianggap suatu butir instrument valid adalah nilai indeks validitasnya $\geq$ 0,3 . Dengan demikian semua pernyataan yang memiliki tingkat korelasi di bawah 0,3 harus diperbaiki atau diulang karena dianggap tidak valid.

\section{Uji Reliabilitas}

Reliabilitas diartikan sebagai tingkat kepercayaan dari hasil suatu pengukuran yang mampu memberikan hasil ukur terpercaya (reliable). Realibilitas merupakan salah satu ciri atau karakter utama instrument pengukuran yang baik.

Ide pokok dalam konsep reliabilitas ini adalah sejauh hasil pengukuran dapat dipercaya yang berarti skor hasil pengukuran tersebut dari kekeliruan pengukuran.

\section{Uji Hipotesis}

\section{Uji T}

Hipotesis dalam penelitian ini dilakukan menggunakan uji t (thitung), sebagai taraf signifikansi untuk melihat pengaruh secara parsial atau sendiri-sendiri.

Variabel bebas konflik kerja berpengaruh terhadap kinerja karyawan

\section{Uji Hipotesis}

Hipotesis dalam penelitian ini dilakukan menggunakan uji t (thitung), sebagai taraf signifikansi untuk melihat pengaruh secara parsial atau sendiri-sendiri. Dengan menggunakan taraf kesalahan $(\alpha) 5 \%$ dan derajat kebebasan $(n-k)$ kemudian $t_{\text {hitung }}$ dibandingkan dengan $t_{\text {tabel }}$ untuk menguji signifikasi. Pengujian hipotesis dilakukan sebagai berikut:

a.$$
\text { maka Ho ditolak dan } H \text { o }
$$

diterima

b. Jika t-hitung > t-tabel maka $\mathrm{Ha}$ diterima dan $\mathrm{Ho}$ ditolak

Ho $: \mu \mathrm{X} 1=0$

Ha $: \mu \mathrm{X} 1 \neq 0$ 
Keterangan:

Tidak terdapat pengaruh yang positif dan signifikan dari variabel (X) terhadap variabel terikat (Y).

Terdapat pengaaruh yang positif dan signifikan dari variabel $(\mathrm{X})$ terhadap variabel terikat (Y).

\section{HASIL DAN PEMBAHASAN Pembahasan}

Berdasarkan pengujian hipotesis pada variabel penelitian diperoleh hasil pembahasan yaitu Konflik Kerja (X_1) nilai t_Hitung $(1,331) \leq$ t_Tabel $(0,681)$ dan tingkat signifikansi $(0,192)$ lebih besar dari 0,05 . Dengan demikian Ho ditolak dan Ha diterima. Artinya terdapat pengaruh secara positif dan signifikan variabel konflik kerja (X1) terhadap variabel kinerja (Y)

Pada variabel Stres Kerja (X_2) nilai t_Hitung $(4,030) \geq \mathrm{t}$-Tabel $(0,681)$ dan tingkat signifikansi $(0,08)$ lebih besar dari 0,05. Dengan demikian Ho ditolak dan $\mathrm{Ha}$ diterima. Artinya terdapat pengaruh secara positif dan signifikan variabel stres kerja (X2) terhadap variabel Kinerja (Y)

Pada variabel Beban Kerja (X_3) nilai t_Hitung $(1,090) \geq$ t_Tabel $(0,681)$ dan tingkat signifikansi $(0,283)$ lebih besar dari 0,05 . Dengan demikian Ho ditolak dan $\mathrm{Ha}$ diterima. Artinya terdapat pengaruh secara positif dan signifikan variabel beban kerja (X3) terhadap variabel Kinerja (Y) pengujian, dari nilai $t_{\text {Hitung }}$ berpengaruh.

\section{Keterangan:}

$$
\begin{array}{lc}
\text { Y } & =\text { Variabel Kinerja } \\
\text { A } & =\text { Konstanta } \\
\text { X_1 } & =\text { Variabel Konflik Kerja } \\
\text { X_2 } & =\text { Variabel Stres Kerja } \\
\text { X_3 } & =\text { Variabel Beban Kerja } \\
€ & =\text { Epsilon (standar error) }
\end{array}
$$

Berdasarkan hasil pengujian dan penelitian yang berkaitan dengan pengaruh konflik kerja, stres kerja dan beban kerja terhadap kinerja karyawan PT. Mutiara Hutama sukses dapat disimpulkan:

a. Hasil hipotesis (H1) dapat membuktikan terdapat pengaruh yang menunjukan hasil penelitian bahwa secara bersama-sama.

b. Bahwa variabel Konflik Kerja (X 1) nilai t Hitung $(1,331) \leq$ t_Tabel $(0,681)$ dan tingkat signifikansi $(0,192)$ lebih besar dari 0,05 . Yang berarti hipotesis dalam hal ini sangat signifikan sekali.

c. Selain itu juga dalam hal ini pengaruh konflik kerja sangat memiliki pengaruh terhadap kinerja karyawan yang dimana saling terikat dan mengikuti variabel lainnya.

Dari penelitian dan hasil analisis yang telah dilakukan mengenai pengaruh-pengaruh konflik kerja terhadap kinerja karyawan PT. Mutiara Hutama Sukses.

Hasil penelitian menunjukan bahwa variabel konflik kerja memiliki pengaruh yang sangat signifikan terhadap kinerja karyawan, hal ini menunjukan bahwa konflik kerja sangat berpengaruh terhadap kinerja karyawan.

Hasil penelitian menunjukan bahwa variabel stres kerja memiliki pengaruh yang sangat signifikan terhadap kinerja karyawan PT. Mutiara Hutama Sukses.

Hasil penelitian menunjukan bahwa variabel beban kerja memiliki pengaruh terhadap kinerja karyawan PT. Mutiara Hutama Sukses

Hasil penelitian menunjukan bahwa variabel kinerja karyawan memiliki keterikatan terhadap variabel konflik kerja, stres kerja dan beban kerja terhadap kinerja 
karyawan di PT. Mutiara Hutama Sukses.

\section{KESIMPULAN}

1. Penelitian ini bertujuan untuk mengetahui pengaruh konflik kerja, stres kerja dan beban kerja terhadap kinerja karyawan PT. Mutiara Hutama Sukses

2. Pengaruh Konflik Kerja Terhadap Kinerja Karyawan, bahwa variabel Konflik Kerja (X_1) nilai t_Hitung $(1,331) \leq$ t Tabel $(0,681)$ dan tingkat signifikansi $(0,192)$ lebih besar dari 0,05 . Dengan demikian Ho ditolak dan Ha diterima. Artinya terdapat pengaruh secara positif dan signifikan variabel konflik kerja (X1)terhadap variabel kinerja (Y)

3. Pengaruh Stres Kerja Terhadap Kinerja Karyawan. Pada variabel stres kerja (X_2) nilai t_Hitung $(4,030)$ $\geq \mathrm{t}$-Tabel $(0,681)$ dan tingkat signifikansi $(0,08)$ lebih besar dari 0,05 . Dengan demikian Ho ditolak dan Ha diterima. Artinya terdapat pengaruh secara positif dan signifikan variabel stres kerja (X2) terhadap variabel Kinerja (Y)

4. Pengaruh Beban Kerja Terhadap Kinerja Karyawan. Pada variabel Beban Kerja (X_3) nilai t_Hitung $(1,090)$ $\geq \mathrm{t}$-Tabel $(0,681)$ dan tingkat signifikansi $(0,283)$ lebih besar dari 0,05. Dengan demikian Ho ditolak dan $\mathrm{Ha}$ diterima. Artinya terdapat pengaruh secara positif dan signifikan variabel beban kerja (X3) terhadap variabel Kinerja
5. Berdasarkan hasil uji f dapat di hitung adalah 30,798 dengan signifikan nilai $\mathrm{f}_{-}$ hitung sebesar 0,000 lebih rendah dari 0,05 sedangkan nilai $\mathrm{F}_{-}$tabel pada tingkat kepercayaan $95 \% \quad(a=0,05)$ adalah 2,87, sehingga $F_{-}$ hitung 30,798> F tabel 2,87.

\section{Saran}

1. Lebih di utamakan lagi perbaikan-perbaikan atau sistem cara kerja yang sesuai

2. Menjadikan penelitian untuk mengurangi konflik kerja, stres kerja dan beban kerja agar pekerjaan atau tanggung jawab sebagai karyawan selalu dijalankan berdampak terhadap perusahaan.

3. Hasil dari penelitian atau uji mengenai adanya konflik kerja, stres kerja sangat mempengaruhi sistem kerja atau manajemen perusahaan sehingga bisa menjadi bahan kajian untuk lebih lagi respon terhadap masalah karyawan agar pekerjaan dan semuanya berjalan lancar.

4. Menurut saya penelitian ini sangat berguna bagi saya dalam hal ini karena proses pembelajaran dan lebih menerapkan lagi cara kerja yang lebih efektif serta dapat dirasakan manaafatnya untuk banyak orang baik itu bagi perusahaan maupun karyawan tentunya.

5. Dari hasil uji-uji yang sudah dilaksanakan dalam penelitian akhir-akhir ini semoga didapatkan sumber daya manusia yang lebih meningkatkan lagi sistem yang baik dalam perusahaan untuk semua karyawan yang ada didalamnya sesuai dengan prosedur yang ada nantinya. 


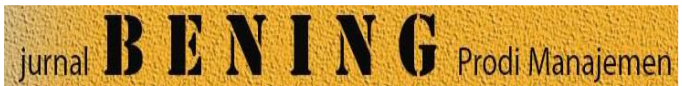

UNIVERSITAS RIAU KEPULAUAN BATAM

\section{DAFTAR PUSTAKA}

Abdul. 2013. "Pengaruh Peraturan Kinerja Karyawan Terhadap Stres Kerja Pada Pada Perusahaan Umum" Cetakan 10 Bandung: Gramedia Pustaka.

Arifin. 2012. Teori Mengenai Manajemen Konflik Kerja Stres Kerja Dan Beban Kerja. Skripsi. Sekolah Tinggi Ekonomi

Darmasyah. 2013. Dampak Stres Kerja Terhadap Sumber Daya Manusia Secara Menyeluruh. Jakarta: Pustaka Manajemen Umum

Dhania, 2012.Indikator - Indikator Beban Kerja Secara Khusus Di Dalam Dunia Kerja. Jurnal Beban Kerja Vol 13 dan 14

Darwin, 2012. Metode Penelitian Bisnis Dan Kuantitatif Data Umum. Edisi ke 15. Surakarta

Ghozali. 2012. Aplikasi analisis multivarete dengan program IBM SPSS. Penerbit: Mitra Karya.

Jhon, 2012. Konflik Kerja Stres Kerja dan Beban Kerja Secara Finansial Diri. Edisi ke 10, Jakarta: Penerbit Mandiri Pustaka Jaya

Mariadi, 2012 ."'Teori Tentang Stres Kerja Di Perusahaan". Edisi ke 15. Jakarta: Kencana Buku Ekonomi

Putra. 2012. Buku Kinerja SDM Organisasi. Bandung: Penerbit Wirasakti Media Pratama 01.

Robbins. 2013. Aplikasi Manjemen Perusahaan Terhadap Karyawan. Edisi Ketiga. Jakarta: Mitra Wacana Media.

Siswandi. 2013. Aplikasi Manajemen Perusahaan Secara Umu. Edisi ke 3. Jakarta: Penerbit Mitra Wacana. Teori Kerangka Pemikiran

Sugiyono, 2014. Metodologi Penelitian Pembahasan
Volume 5 No. 2 Tahun 2018

P-ISSN 2252-5262

E-ISSN 2614-499

Instrumen. Edisi Ke 18 Bandung: Penerbit Alfabeta

Sugiyono, 2014. Metodologi Penelitian Pembahasan Populasi dan Sampel. Edisi ke 18 Bandung: Penerbit Alfabeta

Tarigan dan Suparmoko, 2012. Metode Pengumpulan Data. Edisi Ke 1 Yogyakarta: Granusa Media Pustaka, 130-135

Usman. 2012. Pengaruh Konflik Kerja, Stres Kerja, Beban Kerja Terhadap Kinerja Secara Umum Dan Transparan. Jurnal Ilmu Manajemen.

Velawati, 2012. Analisa Pengaruh Konflik Kerja Stres Kerja dan Beban Kerja Karyawan PDA Binjai. Tesis. Medan: USU 